\title{
Research on the Innovation of Discourse System of Ideological and Political Education in Colleges and Universities in the We-Media
}

\author{
Xiangwei Kong \\ Shangqiu Normal University, 476000, China.
}

\begin{abstract}
The advent of the self-media era has given everyone an opportunity to speak up, but the corresponding supervision mechanism has not been effectively established. College students are easily affected by bad information in the current complex self-media environment. Therefore, colleges and universities in the self-media environment The right to speak in ideological and political education has been greatly challenged. This article conducts research on the reform and innovation of the ideological and political education activity system in colleges and universities under the current self-media environment, in order to improve the effect of ideological and political education in colleges and universities, and guide college students to establish healthier ideological and political concepts.
\end{abstract}

Keywords: Self-media; ideological and political education; discourse system; innovative research

With the development of information technology, people's ways of contacting information have become more and more diversified, and people can also express their opinions and speech freely in this age of self-media prosperity. In light of the current education situation, most college students do not have in-depth contact with the society, and the three personal views and ideological and political concepts have not been fully established. Colleges and universities should seize the opportunity of rapid information dissemination brought by the media age and should also do a good job. Prepare for challenges to their right to speak. Therefore, ideological and political teachers in colleges and universities in the self-media environment should do a good job in ideological and political management, use self-media flexibly, improve and innovate their own speech system, stabilize their own special right to speak, and ensure Ideological and political work in universities can continue to be carried out effectively.

\section{The current situation of the discourse system of ideological and political education in colleges and universities in the self-media environment}

First of all, there are more channels for obtaining information, and people's subjective awareness has increased. In traditional ideological and political education, students and teachers have fewer information channels, and they appear more rigid and formatted when conducting ideological and political education. Since the media era, the number of information channels available to students has increased, and personal subjective awareness has increased. Unilateral preaching does not produce good results. Second, the authority of traditional ideological and political education methods has been challenged. In the self-media era, students are no longer satisfied with passively receiving teachers' ideological and political indoctrination. Students speak independently through self-media, analyze and discuss hot events from various angles, and traditional education methods have been greatly challenged. Finally, the teacher's own education level needs to be improved. The information exchanges brought about by the media age are too rapid, and many ideological and political teachers cannot follow up in time. In addition, the students' hobbies are too wide and it is difficult to effectively control the students. Teachers need to continuously improve their professional ability and keep up with the pace of the times. Only in this way can they re-establish a certain authoritative discourse system for ideological

Copyright (C) 2020 Xiangwei Kong

doi: $10.18282 /$ le.v9i5.1213

This is an open-access article distributed under the terms of the Creative Commons Attribution Non-Commercial License

(http://creativecommons.org/licenses/by-nc/4.0/), which permits unrestricted non-commercial use, distribution, and reproduction in any medium, provided the original work is properly cited. 
and political education in colleges and universities.

\section{Factors affecting the discourse system of ideological and political education in colleges and universities in the self-media environment}

There are many factors that influence the discourse system of ideological and political education in colleges and universities in the self-media environment. In addition to the changes in the information environment brought about by the self-media, there are also the limitations of colleges' own ideological and political education. First, traditional ideological and political education in colleges and universities is limited by a fixed teaching model, and has not fundamentally realized the effective dissemination of ideological and political education discourse. Since the media era, this restriction has been broken, and the students' freedom of speech has been strengthened and weakened in disguise. The discourse system of the university itself. Second, although some colleges and universities have realized the importance of new media to ideological and political education, the topics they set up are still stereotyped and abstract, which cannot stimulate students' enthusiasm for discussion, and the impact of other media information on the Internet, The positive guiding effect is not obvious. Third, teachers themselves do not have sufficient knowledge of the self-media, and many of the content posted are too empty and not close to the actual life of students. The control of ideological and political education on college students has gradually declined, which has severely restricted the reestablishment of the discourse system of ideological and political education in colleges and universities. .

\section{Innovative strategies for the discourse system of ideological and political education in universities under the self-media environment}

\subsection{Change the discourse method of ideological and political education in colleges and universities}

Judging from the current predicament of ideological and political education in colleges and universities, a large part of it is that the interest of contemporary students is not controlled, and the traditional and inherent dogmatic education methods are still used, and no equal and effective communication channels have been established with students. Therefore, if colleges and universities want to improve their discourse power in the self-media environment, they need to rebuild the ideological and political education methods. First of all, in the selection of educational issues, we must take the current hot issues as the starting point, carefully select titles, and attract students to click and watch. Secondly, preaching education should be avoided in the content, and more obvious, simple and clear expressions should be chosen for education, and some interesting topics should be quoted as much as possible to stimulate students' interest in continuing reading. Finally, questions should be asked after the content of the article to guide students to engage in active discussions and encourage students to express their views. Only by forming a good interaction with students can we truly understand what students think, increase the enthusiasm of ideological and political education among students, and enable universities to re-establish the right to speak in ideological and political education.

\subsection{Pay attention to the self-media construction of universities}

If colleges and universities want to regain their educational discourse, they should follow the trend of the times and build their own self-media platform. Therefore, colleges and universities should actively establish their own selfmedia platforms, select outstanding talents related to self-media to build the platform, combine years of experience in ideological and political education, optimize content and form, and choose more active, healthy and positive energy Content to attract students, use the university's own brand effect to expand the news influence in the self-media environment, so that more students can see and understand the latest ideological and political education information, and let students feel that the university is actually serving students For the sake of this, to improve the school's right to speak among students and ensure the effectiveness of ideological and political education.

\subsection{Strengthen teachers' self-media awareness}

Teachers are still the main implementation group of ideological and political education in the current environment. Therefore, it is very important to improve teachers' professional quality and strengthen their awareness of self-media. 
First of all, teachers should lead by example, improve their own moral cultivation, and set a good example for students. Secondly, pay attention to the thinking trends of students in the self-media environment, be familiar with and understand hot news, actively discuss with students, and improve students' ideological and moral standards in a subtle way. Finally, continue to self-summarize and improve. We must know that the self-media era has not only expanded the knowledge of students, but is also the same for teachers. Only by constantly strengthening our professional level can we better carry out ideological and political education.

\section{Oncluding remarks}

All in all, the discourse system of ideological and political education in colleges and universities has been greatly impacted in the self-media era. In order to better adapt to the current society and re-elevate their discourse status, colleges and universities should change the traditional ideological and political education methods, improve teachers' professional qualities, and build their own We media platform actively develops effective communication with students, eliminates false and empty educational theories, and considers we media from a more rational and objective perspective. Only in this way can we effectively improve our own discourse in ideological and political education. right.

\section{References}

1. Qi Le, Liu Ling. Research on the Innovation of Ideological and Political Education in Colleges and Universities Based on the We-Media Environment[J]. Journal of Shanxi Coal Management Cadre College, 2016, 29(002):101102.

2. Qi Le Liu Ling. Research on the innovation of ideological and political education in colleges and universities based on the self-media environment [J]. Journal of Shanxi Coal Management College, 2016(29):102.

3. Li Luping. Exploration of the innovation path of ideological and political education discourse in colleges and universities based on the self-media field [J]. Educational Science (Full Text Edition): 00241-00241. 